\title{
Characterization of Micronutrients in Tofu from Several Cities in Java Island Indonesia
}

\author{
Woro Yatu Niken SyAHFITRI, Syukria KuRniAWATI, Natalia ADVENTINI, \\ Djoko Prakoso Dwi Atmodjo, Indah Kusmartini, Endah Damastuti, \\ Diah Dwiana LESTIANI and Muhayatun SANTOSO \\ Center for Applied Nuclear Science and Technology, Bandung 40132, Indonesia \\ (Received June 1, 2019)
}

\begin{abstract}
Summary Tofu is a traditional food such as curd made from soymilk with additional coagulants which is widely consumed by people in Indonesia and Asian countries. Tofu is one of the important sources of micronutrients, such as cobalt (Co), chromium (Cr), iron $(\mathrm{Fe})$, selenium (Se) and zinc (Zn). Therefore, the content of various elements both toxic and essential need to be studied to ensure the food safety and estimating their contribution to daily intake. Methods: In this research, the determination of micronutrient content in tofu was carried out in the samples collected from traditional market in Jakarta, Yogyakarta, West, Central and East Java Provinces during the period 2010-2014. Determination of elemental concentration was carried out using neutron activation analysis (NAA) methods. Results: Analysis result showed that the elemental concentrations of $\mathrm{Co}, \mathrm{Cr}, \mathrm{Fe}, \mathrm{Se}$ and $\mathrm{Zn}$ in tofu were in the range of $0.001-0.27 ; \leq 0.001-0.35 ; \leq 0.050-62.90 ; \leq 0.0046-5.34$ and $0.02-21.19 \mathrm{mg} / \mathrm{kg}$ respectively. The daily intake value of tofu is calculated by estimating their contribution based on the concentration and consumption data. The average daily intake of $\mathrm{Co}, \mathrm{Cr}$, Fe, Se and Zn contributes to $1.33-11.95 ; 2.10-2.93 ; 2.66-5.99,13.1$ and $1.95-2.69 \%$ of RDA values for adult women and men. Conclusions: The analysis shows that there are variations in the concentration of micronutrients contained in tofu from the five provinces. Tofu has contributed RDA of $\mathrm{Co}, \mathrm{Cr}$, Fe, Se, and $\mathrm{Zn}$ in almost all regions observed, tofu consumption contributed only a low fraction of RDA value for an adult.
\end{abstract}

Key Words tofu, micronutrient, Java, neutron activation analysis

Soy products have been consumed increasingly nowadays because of its highly beneficial components content. Soy products are widely distributed, such as tempeh, natto, douchi, soymilk, tofu and others $(1,2)$. Tofu resembles a soft white cheese from water extracted and salt or acid coagulated soy protein gel with water, soy lipids, and other constituents trapped on its tissue. This product was developed in China and spread through East Asia. It was used in western cuisine for less than $100 \mathrm{y}$. Tofu serves as an inexpensive, highly digestible protein source. It has played an important role in their nutrition as a source of high protein food $(3,4)$ and one of the important sources of micronutrients, such as Co, $\mathrm{Cr}, \mathrm{Fe}, \mathrm{Se}$, and Zn.

The amount of $\mathrm{Co}, \mathrm{Cr}, \mathrm{Fe}$, Se and $\mathrm{Zn}$ intake by a human is straightly related to their element concentration in foodstuff (5). Information on micronutrient content of tofu listed in Food Composition Tables in Indonesia is still not complete. Therefore the levels of essential and toxic elements in consumed food products need to be determined and estimating their contribution to daily intake.

Micronutrients especially micro minerals have many functions as an important influence on health in human biology. They have a variety of biochemical func-

E-mail: worosyahfitri99@gmail.com tions, mostly as a catalyst for enzymatic activity in human bodies (5-7). Some essential minerals are Co, $\mathrm{Cr}$, $\mathrm{Fe}$, Se, and $\mathrm{Zn}$.

Cobalt is a part of vitamin B12, stimulates the production of red blood cells and is related to the activities of the brain and nervous system $(5,6)$. Chromium is needed for maintaining normal blood glucose levels (6). Iron is one of the major micro-minerals required during pregnancy and adequate iron is required from conception, throughout the pregnancy, and during lactation. It is a component of hemoglobin and numerous enzymes, where it prevents microcytic hypochromic anemia $(5,6)$.

Selenium is involved in important biological activities, especially related to hormones metabolism and the immune system due to its antioxidant and anticancer properties $(6,7)$. The main functions of Se are making special proteins, stimulating the immune system, as a component of the enzyme that activates the thyroid hormone, protecting the organism from viruses and helping in detoxification processes (8). Zinc is an important constituent of various enzymes that help maintain the structural integrity of proteins and expression connected to the metalloproteinases, which are involved in processes of gene regulation $(6,7)$.

Indonesia is one of the tofu producers that quite productive either home or industrial scale with a number 
Table 1. Quality control assessment using NIST Wheat Flour 1567a SRM.

\begin{tabular}{|c|c|c|c|c|c|c|}
\hline \multirow{2}{*}{ Elements } & \multicolumn{4}{|c|}{ SRM NIST WF 1567a } & \multicolumn{2}{|c|}{ Acceptable (15) } \\
\hline & $\begin{array}{l}\text { Certified Value } \\
\quad(\mathrm{mg} / \mathrm{kg})\end{array}$ & $\begin{array}{l}\text { Result } \\
(\mathrm{mg} / \mathrm{kg})\end{array}$ & $\begin{array}{c}\text { Accuracy } \\
\%\end{array}$ & $\begin{array}{l}\text { Precision } \\
\text { \%RSD }\end{array}$ & $\begin{array}{c}\text { Accuracy range } \\
\%\end{array}$ & $\begin{array}{l}\text { Precision } \\
\% \text { RSD }\end{array}$ \\
\hline $\mathrm{Fe}$ & $14.10 \pm 0.50$ & $14.10 \pm 3.09$ & 100 & 10.95 & $80-110$ & 7.3 \\
\hline $\mathrm{Se}$ & $1.1 \pm 0.20$ & $1.04 \pm 0.17$ & 95 & 8.37 & $80-110$ & 11 \\
\hline $\mathrm{Zn}$ & $11.60 \pm 0.40$ & $11.50 \pm 1.93$ & 99 & 8.4 & $80-110$ & 7.3 \\
\hline
\end{tabular}

of industries reached 84.000 business units. Tofu is widely consumed by people in Indonesia especially people on Java island because the population people of this island is the largest in Indonesia $(9,10)$. Therefore, we hope Java island can be a representative sample for this characterization of micronutrient in tofu.

The aims of this research were to determine micro mineral as essential minerals in the tofu and to estimate the population's nutrient intake in their diet. The tofu samples were taken based on the most frequently consumed kind of tofu in several areas of Java island. The tofu collected from Jakarta, Yogyakarta, West, Central, and East Java Provinces during the period 2010-2014.

\section{MATERIALS AND METHODS}

Materials. Wheat Flour Standard Reference Material (SRM) 1567a was obtained from the National Institute of Standards and Technology, demineralized water $(>18 \mathrm{M} \Omega \mathrm{cm})$. Other materials used were the multi-elements standard solutions (ICP E. Merck), titrisol standard solution (E. Merck), polyethylene vials, and tofu samples from various area in Java islands such as Jakarta, Yogyakarta, West, Central, and East Java Provinces.

Subject. The 65 tofu samples were collected from traditional markets in the various region in the five provinces are Jakarta Special Capital District ( 5 areas), West Java (8 areas), Central Java (23 areas), Yogyakarta Special Region ( 3 areas) and East Java (including Madura) (26 areas). The types of collected tofu are white tofu and it has weighed $\pm 500 \mathrm{~g}$ for each sample.

Samples preparations. The tofu was weighed and then mashed together using titanium blade blender. Tofu sample that has been smooth and homogeneous were weighed and placed into small tubes and stored in the freezer until frozen. Freeze-dried at a temperature of $-85^{\circ} \mathrm{C}$ under vacuum. The drying process was taken for $48 \mathrm{~h}$ until the samples dried and had constant weight. Dried samples then refined into a fine powder using a mortar agate, then placed into polyethylene container (11).

Standard preparation. Neutron activation analysis standard was also prepared with pipetted $100 \mu \mathrm{L}$ of ICP multi-element standard solution VI (Merck) into a polyethylene vial. The standard in the vial was then dried by an infrared lamp then sealed by heating ( 8$)$.

Analytical procedure for NAA. As much as $40 \mathrm{mg}$ of sample and NIST 1567 a were each weighed and put into $0.3 \mathrm{~mL}$ polyethylene vials and then sealed by heat. Samples, standard reference material (SRM) 1567a and standard drops were then irradiated along $2 \mathrm{~h}$ at a thermal neutron flux of $10^{13} \mathrm{n} . \mathrm{cm}^{-2} \cdot \mathrm{s}^{-1}$ in rabbit system facilities of the multipurpose reactor the G.A. Siwabessy, Serpong. Samples were left to decay for $1 \mathrm{~d}$ then measured for 55,000 s using a gamma spectrometer with high resolution of $\mathrm{HPGe}$ detector. The spectrum was observed using Genie 2000 software (11).

Daily intake. Daily intake from tofu was calculated for $\mathrm{Co}, \mathrm{Cr}, \mathrm{Fe}$, Se, and $\mathrm{Zn}$ following the equation:

$$
E D I=C \times M
$$

where; $\mathrm{C}$ elements $\mathrm{mg} / \mathrm{kg}$ wet basis and the average per capita daily consumption of tofu (M), using EDI is expressed in $\mathrm{mg} / \mathrm{d}$ and $\mathrm{M}$ was assumed to be $0.020 \mathrm{~kg} /$ person/d for Indonesia (BPS) (12-14). The obtained values were compared with RDA (Recommended Dietary Allowance) or AI (Adequate Intake). Cobalt is no data on RDA and tolerable upper intake level (UL) (5).

\section{RESULTS}

The quality control of analytical results of tofu samples using NAA was evaluated by analyzing SRM NIST 1567a Wheat Flour. The comparison of measured values with the certified values as well as the accuracy and precision of each method that was described as $\%$ recovery and $\%$ CV were provided in Table 1.

\section{DISCUSSION}

Table 1 showed that the resulting accuracy range was 95-100\% and precision 8.37 to $10.95 \%$. Both analytical accuracy and precision were can be accepted according to AOAC international guidelines 80-110\%, while analytical precision is 7.3 to $11 \%$ (15).

A number of 65 tofu samples are collected from a traditional market in the five provinces in Java. This research showed that the elemental concentrations of $\mathrm{Co}, \mathrm{Cr}, \mathrm{Fe}, \mathrm{Se}$ and $\mathrm{Zn}$ in white tofu of Java were in the range of $0.001-0.27$; $\leq 0.001-0.35$; $\leq 0.050-62.90$; $\leq 0.0046-5.34$ and $0.02-21.19 \mathrm{mg} / \mathrm{kg}$ respectively. Table 2 shows the variation within the element concentration obtained from the five regions in Java Island.

Elements contain in food plants as a raw material of tofu are of prime concern. These plants contain the prime resource of essential elements in human nutrition. A little quantity of these mineral compositions of the soil where the seeds planted, type of soil, water, air, and rocks (16). Furthermore, the quality of tofu is influ- 
Table 2. Range values of essential mineral concentrations determined in white tofu from Java Island Indonesia.

\begin{tabular}{|c|c|c|c|c|c|}
\hline \multirow{2}{*}{$\begin{array}{l}\text { Sampling } \\
\text { Location }\end{array}$} & \multicolumn{5}{|c|}{ Essential Mineral (mg/kg wet weigh) } \\
\hline & Co & $\mathrm{Cr}$ & $\mathrm{Fe}$ & $\mathrm{Se}$ & $\mathrm{Zn}$ \\
\hline Jakarta & $0.01-0.03$ & $\leq 0.001-0.03$ & $6.01-62.90$ & 0.01-0.05 & $2.25-12.90$ \\
\hline West Java & $0.01-0.06$ & $\leq 0.001-0.03$ & $10.78-30.67$ & $\leq 0.0046-0.29$ & $4.91-13.63$ \\
\hline Yogyakarta & 0.01-0.02 & $\leq 0.001-0.08$ & $11.63-22.63$ & $0.02-0.07$ & $7.20-11.84$ \\
\hline Central Java & $0.001-0.05$ & $\leq 0.001-0.17$ & $2.50-48.04$ & $\leq 0.0046-0.42$ & $1.56-20.64$ \\
\hline East Java & $0.01-0.27$ & $\leq 0.001-0.35$ & $\leq 0.05-54.31$ & $\leq 0.0046-5.34$ & $0.02-21.19$ \\
\hline
\end{tabular}

Table 3. Recommended Dietary Allowance for adult men and women $>19$ y old ( 7$)$.

\begin{tabular}{lll}
\hline \multirow{2}{*}{ Element } & \multicolumn{2}{c}{$\mathrm{RDA}(\mathrm{mg} / \mathrm{d})$} \\
\cline { 2 - 3 } & Men & Women \\
\hline Co & $0.005^{*}$ & $0.045^{*}$ \\
$\mathrm{Cr}$ & 0.035 & 0.025 \\
$\mathrm{Fe}$ & 8 & 18 \\
$\mathrm{Se}$ & 0.055 & 0.055 \\
$\mathrm{Zn}$ & 11 & 8 \\
\hline
\end{tabular}

*The range biological control on Co.

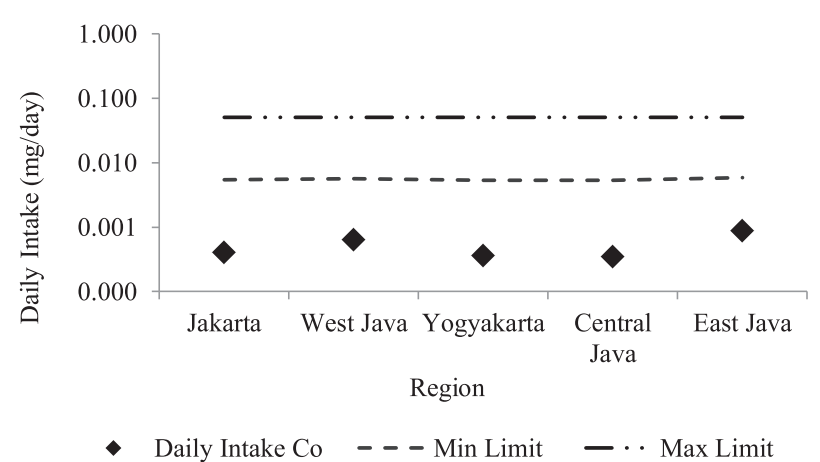

Fig. 1. Co daily intake from the contribution of tofu.

enced by soybean quality, soybean variety, processing conditions and coagulants (2).

The Fe, Se and Zn content of tofu similar to those from the United States Department of Agriculture (USDA) data value of $53.6,0.08$ and $8 \mathrm{mg} / \mathrm{kg}$, respectively (17). The Co and $\mathrm{Cr}$ content of tofu range from 0.001 to 0.27 and $\leq 0.001$ to $0.35 \mathrm{mg} / \mathrm{kg}$. The range concentration of $\mathrm{Co}$ and $\mathrm{Cr}$ from 5 provinces was similar those the value from France is 0.016 and 0.222 $\mathrm{mg} / \mathrm{kg}$ fresh weight (18). Humans require cobalt and chromium in trace amounts. Cobalt is present in small amounts in most foods, deficiency of it is rarely found. Lack of Co may lead to pernicious anemia which can be health problems. Chromium is present at very low levels in food. That is primarily found in two forms, Cr (III), which is biologically active, and $\mathrm{Cr}$ (VI), which is a pollutant and potentially toxic (7).

The concentration of Fe in 65 samples from five prov-

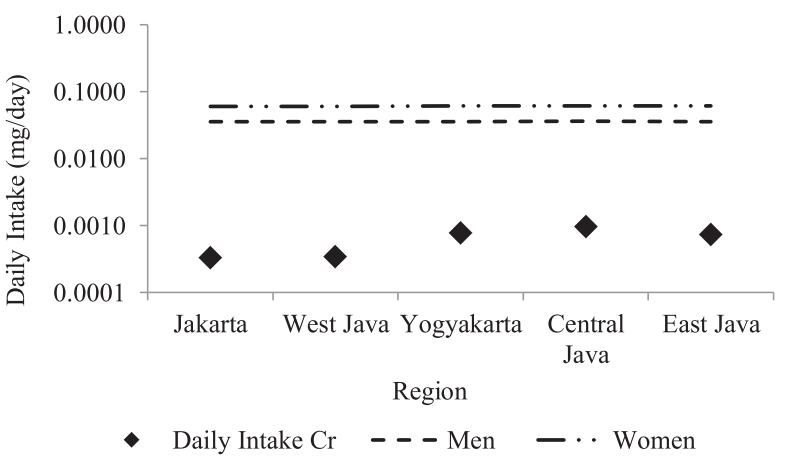

Fig. 2. Cr daily intake from the contribution of tofu for adult $(>19 \mathrm{y})$.

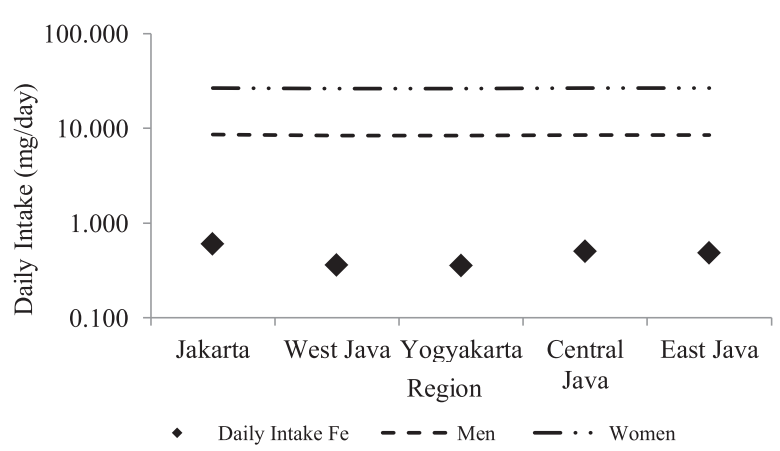

Fig. 3. Fe daily intake from the contribution of tofu for adult ( $>19 \mathrm{y})$.

inces in Java is presented in Table 2. From the table, it can be seen that tofu with the highest average Fe concentration than another element, because $\mathrm{Fe}$ is the fourth most common element in the earth's crust and is abundant in soils (19).

Dietary intake levels of essential minerals from tofu for Javanese people were estimated. In assessing the daily intake, the mean concentration of each element in tofu was multiplied by the consumption rate for Indonesian people. The consumption rate of Indonesian was $0.020 \mathrm{~kg} / \mathrm{person} / \mathrm{d}$. The daily intake values were compared with the Recommended Dietary Allowance (RDA). The RDA value for adult man and women are described in Table 3 as follow.

The estimated daily intake (EDI) values and their comparison with the RDA are shown in Figs. 1-5.

Figures 1-5 shows in almost all regions observed, tofu consumption contributed only to a low-level frac- 


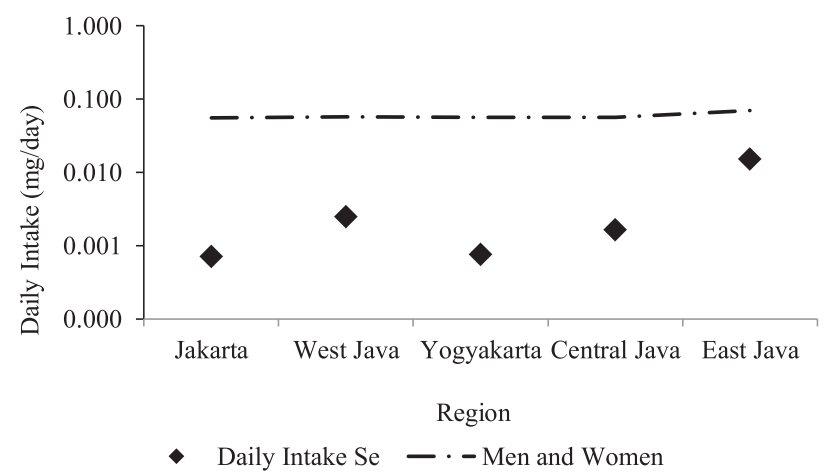

Fig. 4. Se daily intake from the contribution of tofu for adult $(>19 \mathrm{y})$.

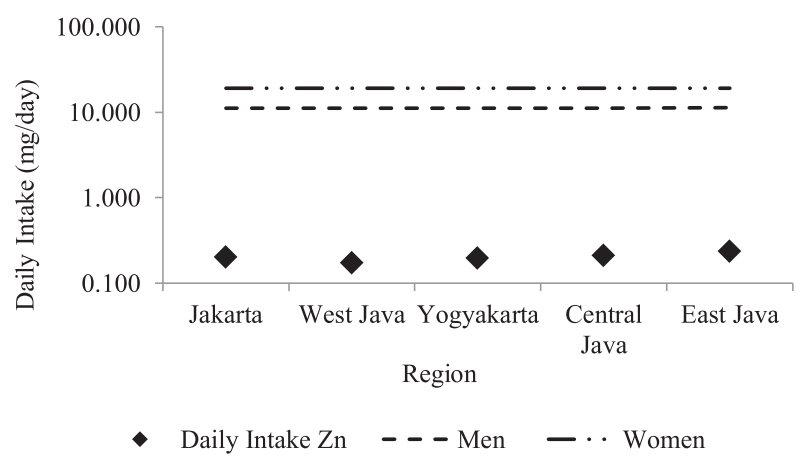

Fig. 5. Zn daily intake from the contribution of tofu for adult $(>19 \mathrm{y})$.

tion of RDA value adult. The average daily $\mathrm{Co}, \mathrm{Cr}, \mathrm{Fe}, \mathrm{Se}$, and $\mathrm{Zn}$ intake contributes to $1.33-11.95 ; 2.10-2.93$; 2.66-5.99, 13.1 and 1.95-2.69\% of RDA values for adult.

Figure 1 shows the cobalt intake is no data on RDA and tolerable upper intake level (UL). The UL is the highest level of daily nutrient intake that does not pose a risk of adverse health effects to almost all individuals in the general population. Daily intake Co similarly to the previous elements, the average Co intakes were below minimal value for biological control on metal $(5 \mu \mathrm{g} / \mathrm{d})$. The intake was still within the normal range and the safe limit for Co which is from 0.005 to $1.8 \mathrm{mg} / \mathrm{d}$ (7).

Figure 4 shows that the selenium daily intake of tofu in East Java appropriate the RDA than other provinces. This variation in Se levels may occur due to the availability in soil. In addition, the concentration of Se can be different not only between samples collected from the different countries in the world but even between samples from different regions of a specific country. Although soil Se concentrations of the geographic origin of the crop are the main determinant of the Se content of foods $(13,20)$.

Tofu is one of the foods that can be an important dietary source of $\mathrm{Co}, \mathrm{Cr}, \mathrm{Fe}, \mathrm{Se}$, and $\mathrm{Zn}$, as it can provide more than $1 \%$ of the RDA. However, its contribution to the elements is highly dependent on the type of soybeans as raw material and coagulant.

\section{In summary}

The results indicate that tofu is one of the foods that have the potential as a source of microminerals such as $\mathrm{Co}, \mathrm{Cr}, \mathrm{Fe}, \mathrm{Se}$, and $\mathrm{Zn}$. The microminerals contained on tofu contribute as it can provide more than $1 \%$ of the RDA. To meet the needs of microminerals, it is recommended to consume a balanced menu.

\section{Disclosure of state of COI}

No conflicts of interest to be declared.

\section{Acknowledgments}

The authors would like to extend their thanks to the Center of Multipurpose Reactor and Center for Applied Nuclear Science and Technology, National Nuclear Energy Agency, Indonesia.

\section{REFERENCES}

1) Zhang Q, Qin W. 2018. Tofu and Soy Products: The Effect of Structure on Their Physicochemical Properties. Elsevier, 1-9.

2) Shobowale OA, Ajiboye AA. 2011. Coagulants modulate the yield and micronutrient composition of tofu. World Journal of Dairy dan Food Sciences 6(1): 67-70.

3) Toole DKO. 2016. Soybean Soymilk, Tofu, and Okara, 2nd ed., Elsevier Ltd., the previous edition 3: 185-195.

4) Fasoyiro SB. 2014. Physical, chemical and sensory qualities of roselle water extract-coagulated tofu compared with tofu from two natural coagulants. Nigeria Food J 32: 97-102.

5) Damastuti E, Syahfitri WYN, Santoso M, et al. 2012. Assessment of trace element daily intake based on consumption rate of foodstuffs in Bandung City. Atom Indonesia 38: 29-34.

6) Chi Eung Danforn Lim. 2009. The role of micronutrients in pregnancy. Aust Fam Physician 38: 980-984.

7) Syahfitri WYN, Damastuti E, Adventini N, Atmodjo DPD, Kusmartini I, Kurniawati S, Lestiani DD, Santoso M. 2018. Essential minerals of rice in West Java Indonesia and its daily intake estimation. Atom Indones 44: 29-34.

8) Kurniawati S, Lestiani DD, Damastuti E, Santoso M. 2019. The selenium content of Tempeh in Indonesia and its potential contribution to the dietary selenium requirements for adults. J Food Compos Anal $\mathbf{8 2}$.

9) Widayat, Philia J, Wibisono J. 2018. Cultivation of microalgae Chlorella sp on fresh water and waste water of tofu industry. E3S Web of Conferences 31: 04009.

10) BPS. 2018. Statistik Indonesia 1-762.

11) Syahfitri WYN, Kurniawati S, Adventini N, Damastuti E, Lestiani DD. 2017. Macro elemental analysis of food samples by nuclear analytical technique. J Phys Conf Ser 860: 012023.

12) Adeyemi JA, Adedire CO, Paulelli AC, et al. 2016. Levels and daily intake of lead $(\mathrm{Pb})$ and six essential elements in gari samples from Ondo State, Southwest Nigeria: A potential risk factor of health status. J Food Compos Anal 45(34): 34-38.

13) Pedron T, Segura FR, Da Silva FF, et al. 2016. Essential and non-essential elements in Brazilian infant food and other rice-based products frequently consumed by children and celiac population. J Food Compos Anal 49: 78-86.

14) Pinto E, Almeida A, Ferreira IMPLVO. 2016. Essential 
and non-essential/toxic elements in rice available in the Portuguese and Spanish markets Edgar. J Food Compos Anal 48: 81-87.

15) Gustavo Gonzalez A, Herrador M. 2007. A practical guide to analytical method validation, including measurement uncertainty and accuracy profile. TrAC-Trends Anal Chem 26: 227-238.

16) Fahad SM, Islam AFMM, Ahmed M, Uddin N, Alam R, Alam F, Khalik F, Hossain S, Hossain L. 2015. Determination of elemental composition of Malabar spinach, lettuce, spinach, hyacinth bean, and cauliflower vegetables using proton induced X-Ray emission technique at Savar Subdistrict in Bangladesh. BioMed Research Inter- national 2015: 1-11.

17) USDA. 2019. Tofu, raw, regular, prepared with calcium sulfate. [Online; accessed 4/1/2019]. https://fdc.nal. usda.gov/fdc-app.html\#/food-details/172476/nutrients.

18) Noel L, Chotri R, Millor S, et al. 2012. Li, Cr, Mn, Co, Ni, $\mathrm{Cu}, \mathrm{Zn}, \mathrm{Se}$ and Mo levels in foodstuffs from the second French TDS. Food Chem 132: 1502-1513.

19) Annonimous. 2017. Micronutrients For Soybeans Production in the North Central Region. Iowa State University Extension.

20) Nazemi L, Nazmara S, Eshraghyan MR, et al. 2012. Selenium status in soil, water and essential crops of Iran. Iranian J Environ Health Sci Eng 9: 11. 